\title{
A risk assessment of leaching from artificial soil composed of fly ash and sludge
}

\author{
Jie Wan ${ }^{1,2}$, Xiaofan Yang ${ }^{*}$, Xiaoping $\mathrm{Xu}^{3}$, Xueyu Wei ${ }^{3}$ \\ ${ }^{1}$ College of Biological and Chemical Engineering, Anhui Polytechnic University, Wuhu 241000, China \\ ${ }^{2}$ College of Environment, Hohai University, Nanjing 210098, China \\ ${ }^{3}$ The School of Civil Engineering and Architecture, Anhui Polytechnic University, Wuhu 241000, China
}

\begin{abstract}
Mixture of fly ash (FA) and sewage sludge (SS) has been used as substrates to plant vegetables and turf grasses. Most studies chemically analyzed physiochemical properties of leachates from FA/SS mixtures, but did not considered the effects of plants growing on leaching properties, and the toxicity of leachates on aquatic animals were not well understood. In the present study, FA and SS were mixed in different ratios and then used to cultivate Zoysia matrella and Cynodon dactylon. After one month, these artificial soils were irrigated with water and leachates were collected for three months. Chemical analyses revealed that, although the heavy metal concentrations of FA and SS almost conformed to the relevant national standards, the levels of $\mathrm{Cr}, \mathrm{Zn}, \mathrm{Cd}, \mathrm{Pb}$ and $\mathrm{Cu}$ in leachates still exceeded the limits in the Chinese Standard of Surface Water Quality, displaying potential environmental hazards. The effects of leachates on reproduction of Daphnia magna were evaluated and the results showed that leachates from high proportion of FA or SS would both negatively affect D. magna, demonstrating an environmental risk. However, leachates from mixture with FA: SS ratio from 1: 2 to 1: 6 did not significantly affect D. magna. Overall, the present results suggested that applications of FA/SS mixtures as artificial soil potentially contaminated aquatic environments and should be monitored carefully.
\end{abstract}

\section{Introduction}

Treatment of sewage sludge (SS) is a major problem worldwide, which is produced in large amount daily. Due to limited space in rural area, landfilling becomes an impractical method to deal with SS. The utilization of sewage sludge in agriculture is an alternative way, because SS generally contains organic matters (such as N, $\mathrm{P}$ and $\mathrm{K}$ ) and relatively lower level of essential elements (such as $\mathrm{Ca}, \mathrm{S}$ and $\mathrm{Mg}$ ) [1]. Fly ash (FA) is a combustion product of coals and contains most essential elements $(\mathrm{Ca}, \mathrm{K}, \mathrm{Na}, \mathrm{Mg})$, but is deficient in $\mathrm{N}$ and other organic matters [2]. Thus, mixture of FA and SS would contain both organic matters and essential elements, which is a suitable artificial soil for plant growth.

One shortcoming of FA/SS artificial soil in agriculture is the high level of heavy metals [3-5] and organic pollutants [6]. The leaching of FA/SS mixture might cause secondary pollution to aquatic environments and soils [7]. Thus, cultivation of food plants on these areas is not a good idea, since metal pollutants might transfer from soil to animals and then endanger human body [8]. Cultivation of non-food plants could avoid this problem, such as turf grasses. However, the potential pollution of leachate to aquatic environments should not be ignored.

Leaching characteristics of FA/SS mixtures have been well chemically analyzed at different conditions [9-
13], but the leaching properties of FA/SS mixtures with plants growing on were not well investigated. Well known, the species and concentrations of heavy metals in leachate varied among sources of FA and SS. However, chemical analysis alone could not accurately evaluate the toxicity of leachate, since potential interactions (synergistic or antagonistic effects) might exist among various heavy metals and organic pollutants [14]. Tests using living aquatic organisms are required to completely assess the environmental hazards of leachate from FA/SS mixture.

The present study aimed to access the physiochemical properties and toxicity of leachate from FA/SS mixture. FA and SS were mixed in different ratios, which were then used to plant turf grasses (Zoysia matrella and Cynodon dactylon). Natural rainfall was mimicked to collect leachate from FA/SS mixture. The concentration of heavy metals in leachate and the effects of leachate on reproduction of the aquatic organism Daphnia magna were investigated. These esult would be useful to environmentally evaluate the application of FA/SS mixture as artificial soil.

\section{Experimental materials and methods}

\subsection{Preparation of artificial soil}

\footnotetext{
* Corresponding author: xiaofan108@ahpu.edu.cn
} 
SS and FA was collected from the Waste Water Treatment Plant of Zhujiaqiao (Wuhu, China) and the coal power plant of Wanwei Group (Wuhu, China), respectively. Both of them were air-dried $\left(19-26^{\circ} \mathrm{C}\right)$ for 28 days and sieved using a $2-\mathrm{mm}$ sieve. FA and SS were mixed in $1: 1,1: 2,1: 4$, and $1: 6$ as four treatments. Meanwhile, pure SS was also included.

\subsection{Cultivation of turf grasses}

Two plant species, Z. matrella and C. dactylon, were employed in the present study as independent treatments. In each polypropylene container $(20 \times 15 \mathrm{~cm}), 1 \mathrm{~kg}$ of artificial soil was placed at the bottom (Figure 1). Then, seeds were sowed and kept in a greenhouse at $25 \pm 2{ }^{\circ} \mathrm{C}$. At the first month, the moisture of soil was maintained at $50 \%-70 \%$ to ensure that no liquid was leached. Afterwards, each treatment was irrigated with $3.0 \mathrm{~L}$ of demonized water ( $\mathrm{pH}$ was 6.5-7.5) each month, according to the local annual average rainfall (approximately $1.2 \mathrm{~cm}$ in Wuhu city). Leachates were collected using bottles. The leaching process was kept for 3 months and all leachates from the same treatment was pooled as one sample. All samples were filtered through $0.45 \mu \mathrm{m}$ polycarbonate membrane filters and stored at $4^{\circ} \mathrm{C}$.

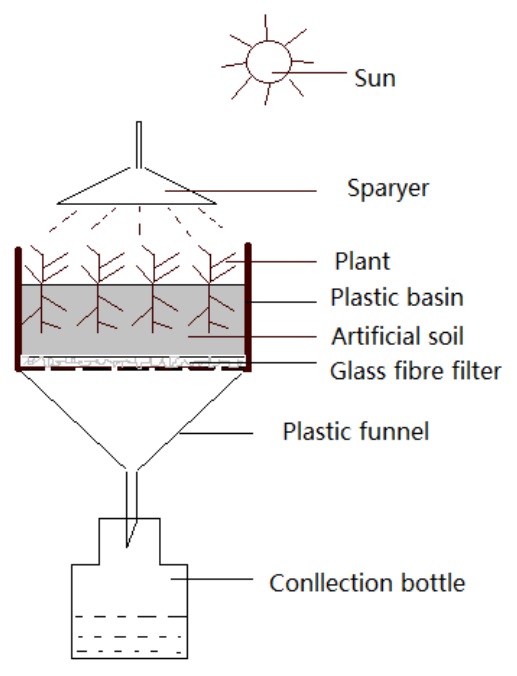

Figure 1. The sketch of planting and leaching equipment

\subsection{Chemical analysis of artificial soil and leachates}

The $\mathrm{pH}$ value and concentrations of $\mathrm{Cd}, \mathrm{Ni}, \mathrm{Cu}, \mathrm{Zn}, \mathrm{Cr}$ and $\mathrm{Pb}$ in $\mathrm{SS}, \mathrm{FA}$ and leachates were determined using ICP-MS (Perkin-Elmer/Sciex Elan 9000, USA).

\subsection{Chronic toxicity of leachate on reproduction of D. magna}

D. magna was obtained from the Chinese Center for Disease Control and Prevention (Beijing, China) and then clonally cultured under controlled laboratory conditions (light: dark $=16 \mathrm{~h}: 8 \mathrm{~h}, 20 \pm 1{ }^{\circ} \mathrm{C}$ ) for more than one month. Culture medium [15] was changed twice a week and D. magna was fed with the green algae Scenedesmus obliquus at $2.0 \times 10^{6}$ cells $/ \mathrm{mL}$ daily. $S$. obliquus was grown in a semi-continuous culture using HB-4 medium [16] renewed daily at 50\% and concentrated by centrifugation before use. The effects of leachates on reproduction of D. magna were assessed in a semi-static test according to the OECD standard protocol [17]. The tests were performed in $10 \mathrm{~mL}$ glass beakers containing $5 \mathrm{~mL}$ of test solution. Each beaker contained one animal, which was repeated for 20 times. D. magna was fed with $2.0 \times 10^{6}$ algae cells per animal daily. Each day, the original animal was carefully transferred to new beaker with fresh test solution; the newly hatched animals were counted and discarded. The experiments were continued for 21 days.

Time of the first pregnancy and the first brood, number of offspring in the first brood and average number of offspring per brood were calculated. The intrinsic rate of population increase was calculated according to Lotka [18] using the formula $\sum l_{x} m_{x} e^{-r x}=1$, where $x$ means time, $l_{x}$ and $\mathrm{m}_{\mathrm{x}}$ is the age-specific survivorship and the age-specific fecundity at age $x$, respectively.

\subsection{Statistical analysis}

Data were expressed as mean \pm standard deviation (SD), and were analyzed using one-way analysis of variance (ANOVA) and SNK tests to detect differences among treatments. Differences were considered significant at $P$ $<0.05$. All the statistical analyses were performed using SPSS 22.0 (SPSS Co., Chicago, IL, USA).

\section{Results and discussion}

\subsection{Chemical analysis}

The heavy metal concentrations of FA and SS are presented in Table 1.

Table 1. Heavy metal concentrations in fly ash and sewage sludge ( $\mathrm{mg} / \mathrm{kg}$ of dry basis).

\begin{tabular}{cccccccc}
\hline $\begin{array}{c}\text { Heavy } \\
\text { metal }\end{array}$ & $\mathrm{pH}$ & $\mathrm{Cd}$ & $\mathrm{Ni}$ & $\mathrm{Cu}$ & $\mathrm{Zn}$ & $\mathrm{Cr}$ & $\mathrm{Pb}$ \\
\hline Fly ash & 11.2 & 3.5 & 67.2 & 133 & 110 & 34 & 166 \\
$\begin{array}{c}\text { Sewage } \\
\text { sludge }\end{array}$ & 7.5 & 12.2 & 112 & 226 & 840 & 189 & 62 \\
\hline
\end{tabular}

Compared with the threshed values in national standards (Table 2), the concentrations of heavy metals in SS were lower than the limited standards in USA (EPA 503 Biosolids Rule, 1993), EEC (86/278/EEC, 2000) and China (GB 4284-84) of SS for agricultural application, expect that the concentration of $\mathrm{Zn}$ (840 $\mathrm{mg} / \mathrm{kg}$ ) was little higher than the limited value (500 $\mathrm{mg} / \mathrm{kg}$ ). The concentrations of heavy metals in FA were all lower than the limited value in the Chinese Control Standards for Pollutants in Fly ash for Agriculture Use (GB 8173-87, China). These results suggested that the 
materials used in the present study nearly conformed to the national standards, which could represent general situation in reality.

Table 2. Threshold values of heavy metals in sludge and fly ash for agriculture and garden plants ( $\mathrm{mg} / \mathrm{kg}$ dry mater).

\begin{tabular}{|c|c|c|c|c|c|}
\hline $\begin{array}{l}\text { Heavy } \\
\text { metals }\end{array}$ & $\begin{array}{l}\text { USEPA503 } \\
\text { Biosolids } \\
\text { Rule } \\
\text { sludge) } \\
\end{array}$ & $\begin{array}{l}86 / 278 / \mathrm{EEC} \\
\text { Directive } \\
\text { (sludge) }\end{array}$ & $\begin{array}{l}\text { GB 4284-84 in China } \\
\text { sludge* for agriculture }\end{array}$ & $\begin{array}{l}\text { GBT23486-2009 in } \\
\text { China } \\
\text { sludge* for garden plants }\end{array}$ & $\begin{array}{l}\text { GB 8173-87 in China } \\
\text { fly ash* }\end{array}$ \\
\hline Cd & 85 & $20-40$ & $\begin{array}{l}5(\mathrm{pH}<6.5), 20 \\
(\mathrm{pH} \geq 6.5)\end{array}$ & $\begin{array}{l}5(\mathrm{pH}<6.5), 20 \\
(\mathrm{pH} \geq 6.5)\end{array}$ & $\begin{array}{l}5(\mathrm{pH}<6.5), 10 \\
(\mathrm{pH} \geq 6.5)\end{array}$ \\
\hline $\mathbf{N i}$ & 420 & $300-400$ & $\begin{array}{l}100(\mathrm{pH}<6.5), 200 \\
(\mathrm{pH} \geq 6.5)\end{array}$ & $\begin{array}{l}100(\mathrm{pH}<6.5), 200 \\
(\mathrm{pH} \geq 6.5)\end{array}$ & $\begin{array}{l}200(\mathrm{pH}<6.5), 300 \\
(\mathrm{pH} \geq 6.5)\end{array}$ \\
\hline $\mathrm{Cu}$ & 4300 & $1000-1750$ & $\begin{array}{l}250(\mathrm{pH}<6.5), 500 \\
(\mathrm{pH} \geq 6.5)\end{array}$ & $\begin{array}{l}800(\mathrm{pH}<6.5), 1500 \\
(\mathrm{pH} \geq 6.5)\end{array}$ & $\begin{array}{l}250(\mathrm{pH}<6.5), 500 \\
(\mathrm{pH} \geq 6.5)\end{array}$ \\
\hline $\mathbf{Z n}$ & 7500 & $2500-4000$ & $\begin{array}{l}500(\mathrm{pH}<6.5), 1000 \\
(\mathrm{pH} \geq 6.5)\end{array}$ & $\begin{array}{l}2000(\mathrm{pH}<6.5), 4000 \\
(\mathrm{pH} \geq 6.5)\end{array}$ & no covered \\
\hline $\mathrm{Cr}$ & 3000 & $1000-1500$ & $\begin{array}{l}600(\mathrm{pH}<6.5), 1000 \\
(\mathrm{pH} \geq 6.5)\end{array}$ & $\begin{array}{l}600(\mathrm{pH}<6.5), 1000 \\
(\mathrm{pH} \geq 6.5)\end{array}$ & $\begin{array}{l}250(\mathrm{pH}<6.5), 500 \\
(\mathrm{pH} \geq 6.5)\end{array}$ \\
\hline $\mathbf{P b}$ & 840 & $750-1200$ & $\begin{array}{l}300(\mathrm{pH}<6.5), 1000 \\
(\mathrm{pH} \geq 6.5)\end{array}$ & $\begin{array}{l}300(\mathrm{pH}<6.5), 1000 \\
(\mathrm{pH} \geq 6.5)\end{array}$ & $\begin{array}{l}250(\mathrm{pH}<6.5=, 500 \\
(\mathrm{pH} \geq 6.5)\end{array}$ \\
\hline
\end{tabular}

$* \mathrm{pH}<6.5$, used in acidic soil; $\mathrm{pH} \geq 6.5$, used in neutral or alkaline soil.

Along with the increasing ratio of FA in artificial soil, $\mathrm{pH}$ value of leachate increased, which should be attributed to the higher $\mathrm{pH}$ value of FA than SS (Fig. 2). Mixture of FA and SS at ratio from 1: 2 to 1: 6 showed almost neutral $\mathrm{pH}$, which should be less harmful to plants. The concentration of $\mathrm{Cr}, \mathrm{Zn}, \mathrm{Ni}, \mathrm{Cd}$ and $\mathrm{Cu}$ in leachates increased with the increasing ratio of $\mathrm{SS}$, probably since the levels of these elements were higher in $\mathrm{SS}$ than FA. The reverse was also true for $\mathrm{Pb}$ (Fig. 2).

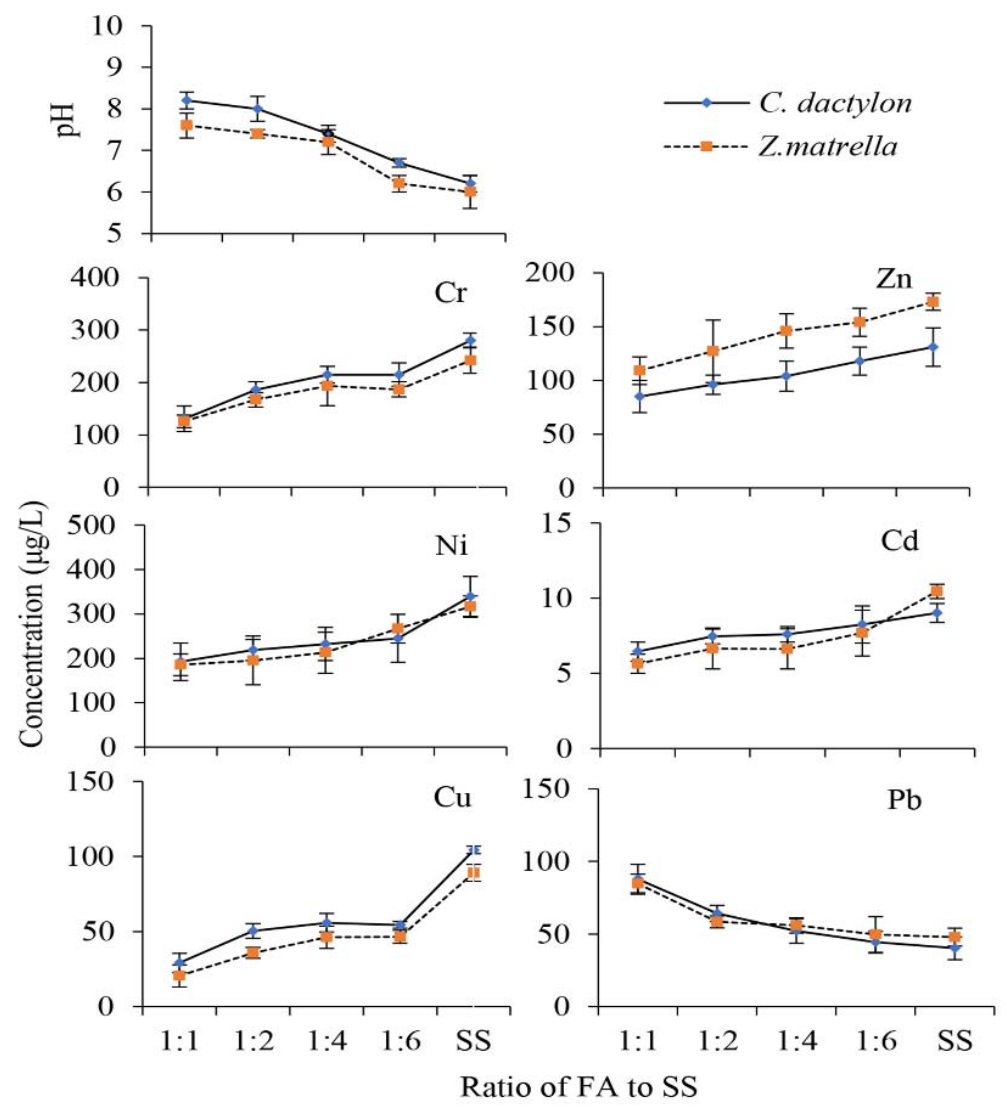

Figure 2. $\mathrm{pH}$ and concentration of heavy metals in leachates from mixture of fly ash (FA) and sewage sludge (SS) after cultivation of C. dactylon and Z. matrella. 
As the Chinese Standard of Surface Water Quality (GB3838-2002) requested, the upper limit of $\mathrm{Cr}, \mathrm{Zn}, \mathrm{Cd}$, $\mathrm{Pb}$ and $\mathrm{Cu}$ level in surface water was $0.1 \mathrm{mg} / \mathrm{L}, 2.0 \mathrm{mg} / \mathrm{L}$, $0.01 \mathrm{mg} / \mathrm{L}, 0.1 \mathrm{mg} / \mathrm{L}$ and $1.0 \mathrm{mg} / \mathrm{L}$, respectively. Although the level of $\mathrm{Cr}$ in both FA and SS did not exceed the relevant national standards, the level of $\mathrm{Cr}$ in leachates of FA/SS was still higher than the limited value for surface water. Well known, $\mathrm{Cr}$ is a typical toxic element and can seriously negatively affect animals and human body. High level of $\mathrm{Cr}$ in leachate would pollute nearby aquatic environments. Thus, application of FA/SS mixture might raise environmental concerns, which should be monitored carefully.

It was reported that plant species might influence the leaching characteristics of heavy metals from artificial soil. For example, $\mathrm{Cr}$ concentration in leachates from treatments with Robina pseudoacacia growth was always higher than those from treatments with Amorpha fruticose [4]. In the present study, the $\mathrm{pH}$ value and concentrations of $\mathrm{Cr}, \mathrm{Ni}, \mathrm{Cd}$ and $\mathrm{Pb}$ were similar in leachates between treatments with $C$. dactylon and $Z$. matrella, suggesting that these two species might not differ in absorption of these elements. In comparison, the level of $\mathrm{Zn}$ in leachates was higher and the level of $\mathrm{Cu}$ was lower in treatments with $Z$. matrella than that with $C$. dactylon. These results suggested that $Z$. matrella and $C$. dactylon might have different ability in $\mathrm{Zn}$ and $\mathrm{Cu}$ absorption. Another possibility was that cultivation of turf grass might affect the solubility of $\mathrm{Cr}$. $\mathrm{Cr}$ exists in environments in diverse forms, such as $\mathrm{Cr}^{3+}$ and $\mathrm{Cr}^{6+}$. Under common environmental conditions of $\mathrm{pH}$ and $\mathrm{Eh}$, $\mathrm{Cr}^{3+}$ is less soluble than $\mathrm{Cr}^{6+}$ [19]. However, complexation with organic ligands might enhance $\mathrm{Cr}^{3+}$ solubility, and changes in Eh or $\mathrm{pH}$ could affect redox transformations of different species of $\mathrm{Cr}$, and adsorption to certain solid phases would also affect such redox reactions $[20,21]$. To the best of our knowledge, there was no reports comparing the ability of heavy metal absorption and the status of $\mathrm{Cr}$ between treatments with Z. matrella and C. dactylon. These viewpoints should be further investigated in future.

\subsection{Chronic toxicity of leachates}

Assessment of chronic toxicity using D. magna is an ordinary method to evaluate environmental risk of pollutants [22]. In the present study, reproduction of $D$. magna was assessed for 21 days in response to treatments with leachates in Table 3. No mortality occurred in all the treatments during the experimental process, demonstrating that leachates of FA/SS mixture did not show high toxicity to $D$. magna.

After cultivation with either $C$. dactylon or $Z$. matrella, treatments with leachates from SS significantly elongated time of first pregnancy and time of first brood in comparison to the control, suggesting that development of D. magna was inhibited. Meanwhile, number of offspring in first brood and number of offspring per brood were both reduced, suggesting inhibitive effects of SS leachate on reproduction of $D$. magna. These results together might lead to the significantly lower intrinsic rate of population increase in treatments with SS leachate. Obviously, leachate of SS displayed significantly inhibitive effects on development and reproduction of D. magna, which might be resulted from the higher level of heavy metals $(\mathrm{Cr}, \mathrm{Zn}, \mathrm{Ni}, \mathrm{Cd}$ and $\mathrm{Cu}$ ) in SS leachate (Fig. 2).

Table 3. Reproduction parameters of $D$. magna exposed to leachates. Treatments represent the ratio of FA to SS in artificial soils. * means significantly different from the control $(P<0.05)$

\begin{tabular}{|c|c|c|c|c|c|}
\hline Treatments & $\begin{array}{l}\text { Time of first } \\
\text { pregnancy } \\
\text { (day) }\end{array}$ & $\begin{array}{c}\text { Time of first } \\
\text { brood } \\
\text { (day) }\end{array}$ & $\begin{array}{l}\text { No. of offspring in first } \\
\text { brood } \\
\text { (ind.) }\end{array}$ & $\begin{array}{l}\text { No. of offspring/brood } \\
\text { (ind.) }\end{array}$ & $\begin{array}{c}\text { Intrinsic rate of } \\
\text { population increase } \\
\text { (/day) }\end{array}$ \\
\hline \multicolumn{6}{|l|}{ C. dactylon } \\
\hline Control & $8.70 \pm 1.02$ & $10.15 \pm 1.23$ & $6.22 \pm 1.01$ & $6.61 \pm 1.03$ & $0.332 \pm 0.221$ \\
\hline $1: 1$ & $6.81 \pm 0.23^{*}$ & $8.36 \pm 1.03 *$ & $7.27 \pm 1.00$ & $6.25 \pm 0.73$ & $0.295 \pm 0.028 *$ \\
\hline $1: 2$ & $8.86 \pm 1.26$ & $10.40 \pm 0.13$ & $6.29 \pm 0.12$ & $6.41 \pm 0.30$ & $0.333 \pm 0.111$ \\
\hline $1: 4$ & $8.55 \pm 1.43$ & $11.67 \pm 1.31$ & $5.92 \pm 1.55$ & $6.67 \pm 1.07$ & $0.359 \pm 0.115$ \\
\hline $1: 6$ & $8.42 \pm 0.41$ & $9.72 \pm 0.36$ & $6.25 \pm 0.121$ & $6.43 \pm 1.29$ & $0.323 \pm 0.264$ \\
\hline SS & $11.63 \pm 1.19^{*}$ & $13.49 \pm 0.72 *$ & $3.29 \pm 0.49^{*}$ & $4.42 \pm 0.418^{*}$ & $0.255 \pm 0.227^{*}$ \\
\hline \multicolumn{6}{|l|}{ Z. matrella } \\
\hline Control & $7.41 \pm 1.32$ & $9.89 \pm 1.00$ & $7.10 \pm 1.21$ & $8.29 \pm 1.14$ & $0.342 \pm 0.021$ \\
\hline $1: 1$ & $6.47 \pm 0.63^{*}$ & $8.16 \pm 0.43 *$ & $7.47 \pm 1.10$ & $7.71 \pm 0.24$ & $0.3115 \pm 0.116$ \\
\hline $1: 2$ & $8.55 \pm 1.13$ & $10.32 \pm 1.10$ & $7.91 \pm 1.61$ & $7.72 \pm 1.22$ & $0.335 \pm 0.023$ \\
\hline $1: 4$ & $7.66 \pm 1.35$ & $10.10 \pm 0.93$ & $7.20 \pm 0.82$ & $8.23 \pm 0.30$ & $0.354 \pm 0.132$ \\
\hline $1: 6$ & $7.22 \pm 1.10$ & $9.82 \pm 0.32$ & $6.91 \pm 1.14$ & $7.87 \pm 0.97$ & $0.339 \pm 0.015$ \\
\hline SS & $8.92 \pm 0.44 *$ & $11.26 \pm 1.03 *$ & $6.27 \pm 1.10^{*}$ & $6.25 \pm 0.73 *$ & $0.263 \pm 0.012 *$ \\
\hline
\end{tabular}


In both cultivations of $C$. dactylon and Z. matrella, treatments with leachate from FA/SS with the ratio of 1 : 1 significantly shortened time of first pregnancy and time of first brood, compared with the control, but not affect the reproductive parameters. Moreover, after cultivation of $C$. dactylon, treatment with leachate from FA/SS with the ratio of 1: 1 significantly decreased intrinsic rate of population increase of D. magna, compared with the control, displaying toxic effects to D. magna. These results suggested that leachate of FA/SS mixture with high proportion of FA might also intoxicate aquatic animals.

\section{Conclusions}

Although heavy metal concentrations of FA and SS conformed to the relevant national standards, when the mixture of FA and SS was used as artificial soil to plant C. dactylon and $Z$. matrella, the heavy metal concentrations in leachates still exceeded the limits in Chinese Surface Water Quality, demonstrating potential environmental hazards. Moreover, the leachates from FA/SS mixture with high proportion of either FA or SS would negatively affect production of $D$. magna.

\section{Acknowledgments}

We thank the Shenzhen Nobel Science and Technology Service Company Limited for the comments and language editing service on the present manuscript. This work was supported by the Natural Science Fund of Education Department of Anhui province (KJ2019A0153), the Collaborative innovation project of universities in anhui province(GXXT-2019-034), the National Natural Science Foundation of China (51978001), the Anhui Province Natural Science Foundation (1808085ME133), and the Advanced Research for the National Natural Science Foundation of China (zryy1310, Anhui Polytechnic University).

\section{References}

1. USMAN K., KHAN S., GHULAM S. Sewage sludge: An important biological resource for sustainable agriculture and its environmental implications. Am. J. Plant Sci. 3, (12), 1708, 2012.

2. CARLSON C.L., ADRIANO D.C. Environmental impacts of coal combustion residues. J. Environ. Qual. 22, (2), 227, 1993.

3. ALLOWAY B.J., JACKSON A.P. The behaviour of heavy metals in sewage sludge-amended soils. Sci. Total Environ. 100, 151, 1991.

4. ZHANG H., SUN L., SUN T. Leaching of heavy metals from artificial soils composed of sewage sludge and fly ash. Bull. Environ. Contam. Toxicol. 88, (3), 406, 2012.

5. NIU H., LI S., SHEN J., YAO M. Characteristics of heavy metal accumulation on fly ash- and sewage sludge-amended calcific soil. Chin. J. Geochem. 31, (2), 181, 2012.

6. NYLUND K., ASPLUND L., JANSSON B., JONSSON P., LITZÉN K., Sellström U. Analysis of some polyhalogenated organic pollutants in sediment and sewage sludge. Chemosphere. 24, (12), 1721, 1992.

7. EGIARTE G., CAMPS ARBESTAIN M., RUÍZROMERA E., PINTO M. Study of the chemistry of an acid soil column and of the corresponding leachates after the addition of an anaerobic municipal sludge. Chemosphere. 65, (11), 2456, 2006.

8. ADRIANO D.C., WEBER J.T. Influence of fly ash on soil physical properties and turfgrass establishment. J. Environ. Qual. 30, (2), 596, 2001.

9. FANG W., WEI Y., LIU J., KOSSON D.S., VAN DER SLOOT H.A., ZHANG P. Effects of aerobic and anaerobic biological processes on leaching of heavy metals from soil amended with sewage sludge compost. Waste Manag. 58, 324, 2016.

10. JIAO F., ZHANG L., DONG Z., NAMIOKA T., YAMADA N., NINOMIYA Y. Study on the species of heavy metals in MSW incineration fly ash and their leaching behavior. Fuel Process. Technol. 152, 108, 2016.

11. ZHANG Y., CETIN B., LIKOS W.J., EDIL T.B. Impacts of $\mathrm{pH}$ on leaching potential of elements from MSW incineration fly ash. Fuel. 184, 815, 2016.

12. GU X.Y., WONG J.W.C., TYAGI R.D. 11Bioleaching of heavy metals from sewage sludge for land application. Current Developments in Biotechnology and Bioengineering: Elsevier. 241, 2017.

13. ZHAO S., CHEN Z., SHEN J., KANG J., ZHANG J., SHEN Y. Leaching mechanisms of constituents from fly ash under the influence of humic acid. J. Hazard. Mater. 321, 647, 2017.

14. KUNGOLOS A., AOYAMA I. Interaction effect, food effect, and bioaccumulation of cadmium and chromium for the system Daphnia magna-Chlorella ellipsoidea. Environ. Toxicol. 8, (4), 351, 2010.

15. AGENCY U.S.E.P. Methods for measuring the acute toxicity of effluents and receiving waters to freshwater and marine organisms. Environmental Protection Agency, Washington, DC: U.S. 32, 2002 (In America).

16. ZHANG Z.S., HUANG X.F. Research methods of Freshwater plankton. Science Press: Beijing, 410, 1991(In China).

17. Guidelines for testing of chemicals. Paris: OECD Publishing; 1998 (In French).

18. LOTKA A.J. A natural population norm. J. Wash. Acad. Sci. 3, 241, 1913.

19. ŚWIETLIK R. Speciation Analysis of Chromium in Waters. Pol. J. Environ. Stud. 7, (5), 257, 1998.

20. JACKSON B., MILLER W. Soil solution chemistry of a fly ash-, poultry litter-, and sewage sludgeamended soil. J. Environ. Qual. 29, (2), 430, 2000. 
21. PENG J.F., SONG Y.H., YUAN P., CUI X.Y., QIU G.L. The remediation of heavy metals contaminated sediment. J. hazard. mater. 161, (2), 633, 2009.

22. MENDONÇA E., DINIZ M., SILVA L., PERES I., CASTRO L. Effects of diamond nanoparticle exposure on the internal structure and reproduction of Daphnia magna. J. Hazard. Mater. 186, (1), 265, 2011. 